January 1994

\title{
Sovereignty and Human Rights
}

Robert F. Drinan

Follow this and additional works at: https://scholarlycommons.law.case.edu/cuslj

Part of the Transnational Law Commons

\section{Recommended Citation}

Robert F. Drinan, Sovereignty and Human Rights, 20 Can.-U.S. L.J. 75 (1994)

Available at: https://scholarlycommons.law.case.edu/cuslj/vol20/iss/12

This Speech is brought to you for free and open access by the Student Journals at Case Western Reserve University School of Law Scholarly Commons. It has been accepted for inclusion in Canada-United States Law Journal by an authorized administrator of Case Western Reserve University School of Law Scholarly Commons. 


\title{
Sovereignty and Human Rights
}

\author{
Robert F. Drinan, S.J.*
}

I am always pleased to accept your invitation and to see my good $\mathbf{I}_{\text {friend Henry King. We are very happy to see him so prosperous and }}$ so idealistic. I welcome also my old friend Professor Richard Bilder, whose daughter incidentally is now a professor at my favorite law school, Boston College Law School.

Let me tell you a little story about Cleveland, before we get into the heavy stuff. Two or three years ago, I was flying from the west coast to Washington, and the weather in Washington was wicked. Finally when we were over the Midwest the crew announced that we cannot get into Washington and we have to stop somewhere, and then they changed their announcement and said we might go on. In any event, they eventually came down and landed in Cleveland. I was not thrilled about being in Cleveland that night - I am sorry. But then eventually at 2 a.m. they got us into a motel, and said that they will pick us up in the morning somehow.

I thought I ought to thank God for all the misery he had sent to me that night in Cleveland. So I picked up the Gideon Bible, which is in every hotel room in the world. It tells you in the beginning what to read if you are tired or lonely or afraid, or tempted. And I was lonely that night in Cleveland, and I read the psalm that you read when you are lonely. It was a beautiful prayer, and then written in very carefully. were these words: "If you are still lonely, call 227-4877." Do you want that number again?

I love stories about lawyers. Some of them are terrible, but I heard one the other day that is really cute; it is not too bad.

The lady comes up to the lawyer and says, "Mr. Lawyer, how much do you charge"? And he said, "Madam it is $\$ 100$ for three questions." She said, "That is pretty expensive isn't it?" He replied, "No ma'am, not at all, and what is your third question?"

Well, I thank Dean Gerhart for his nice comments, and I commend him upon all that he, Henry and Professor Picker are doing at your distinguished law school.

By the way, I have a little story about deans; you must have heard that old deans never die, they just lose their faculties.

Well, I am happy that you are having part of this Conference on

* Professor of Law, Georgetown University Law School. The following text was compiled from the transcript of the remarks made by Professor Drinan at the Conference. 
Earth Day. It occurred to me today that this is the 24th anniversary, and that in 1970, when I was first a candidate for Congress, there was the first earth day in Brookline, Massachusetts. My political advisor said, "Do not go to that, they are just a bunch of freaky kids with long hair." Well, somehow I did go, and I was not certain that I enjoyed it, because these kids maybe could not vote or would not vote. In any event, I heard almost for the first time about acid rain, rain forests, global warming and the ozone layer, and I am delighted that now, 24 years later, those kids saying those things are running the EPA.

Well, I am going to give you a story about human rights and $\mathrm{Ca}$ nada and the United States, and if you think that maybe this is a bit of a dream, let me tell you about the original dream in our tradition in Anglo-American law, and that was at Runnymede.

Four years ago the American Bar Association met in London, and it was advertised that there was an excursion of pilgrimage to Runnymede, and Justice Brenner was going to speak there. Well, it was kind of a slow morning so. I said I would go up to Runnymede, and it was one of the most moving experiences of my life, seeing the American Bar Association put a plaque there, thanking the Lords of the Barrons for establishing the Magna Carta. It occurred to me that they never could have had any idea that this would be a world event. And now we are doing the same thing in the international order. When you hear about the rights of children and the rights of women and indigenous people, you may say, "Well those are just dreams." Well, Magna Carta was a dream, and in a very different way, and a very specific way, I think that Americans and Canadians are people who have a dream.

Our forefathers had dreams and they came to this continent and they settled it and advanced beyond any possible expectations. In the United States we have had 52 million immigrants come to our shores. We are those immigrants' children and grandchildren, and we look around the world and say that we want to help those people who are in the same situation as our forefathers were, but they cannot come to America.

What about sovereignty? I like what Professor Louie Henkin said, as quoted this morning; that it is a bit of an anachronism. It sounds like the rhetoric of the powerful nations pushing around the small nations. It is an old, old problem as you know, and Article 27 of the U.N. Charter says it very clearly, that the sovereignty persists and abides because other nations and the United Nations may not interfere with those things which are "within the domestic jurisdiction of one country." That very language dates from the Charter of the League of Nations.

There are of course many exceptions and we see them every single day. For example, the environmental dangers now transcend borders, and likewise the transfer of drugs, and increasingly more trade, as indi- 
cated this morning, is transnational.

All of us dream of the world without tariffs or quotas or boundaries, where we have a worldwide NAFTA or GATT. Are we moving towards that? We might well be. Someone analogized the situation of the world the other day to the situation in America, after the Articles of Confederation. You will recall that the 13 colonies came together looking for some unity. They went as far as they could, and they established a central government. It had no real powers. For many years after the Articles of Confederation there was total anarchy in the 13 colonies. They had tariffs and barriers and rivalry between the north and the south. Finally, the 55 framers of the Constitution came together for the long hot summer in Philadelphia, and they wrote 5,400 words that transformed the country, and yes, the world. They gave power to Washington and they said that certainly all of the states are still sovereign, but that they have to recognize that all the privileges and immunities of America belong to everybody and they may not transgress those. That is what we need in the entire world; is it not?

The small nations will feel that they are getting gobbled up by the large ones. We now have 100 new nations, totally unanticipated when the U.N. Charter was written, and those people are in the ashes of colonialism. They have hatred in their hearts for what the colonial powers did, and they do not trust the European situation. If you speak to the Third World about sovereignty it will always be a very bad name for them. That is what you guys invoke when you do not want to go along and give us some easing of trade barriers.

When we look back to 1945 , we see a total transformation in the law that we used to call "international law." I call it "global law" or "world law." All of those doctrines developed that were mentioned this morning to protect sovereign immunity; are they living on borrowed time, and how soon will sovereignty erode and fade away? No one can predict that, because the 182 nations in the U.N. are very jealous of their prerogatives. They fought a long time to get where they are, and they are not about to say that we are going to alter the structure so that whatever rights we have are submerged.

We followed the definition of self determination, that gospel, and now they are not about to say that we will have our sovereignty trimmed. Human rights were put into the U.N. Charter, as you know, for the first time in human history. Articles 55 and 56 indicate a pledge by all the signatory nations that they will follow human rights. Yes, they pledge to promote human rights in three different ways: They will follow the Charter of the United Nations, they will collaborate with each other, and they will also collaborate in their own initiative.

The United States and the 45 other nations pledged themselves to that, and when we are in doubt about something, I always urge people to go back and say, "What did you pledge to do in San Francisco, at 
that splendid moment where President Truman was presiding over the nations of the earth at that time, the USSR, China, and of course all the allied powers." It was very clear at that time that they put certain things above and beyond the reach of sovereignty, and those things are called human rights. Mr. Truman and many people wanted to incorporate human rights right into the body of the U.N. Charter, and that was not feasible at that time. As you know they had this anxiety, if you will, this desperate, desperate feeling that, yes, there is a New World.

And why did they feel that way? They saw the holocaust, 6 million Jews killed; they saw almost 35 million people perish in

World War II, and they created a document with two specific objectives, namely make a war on war. No one could make war any longer without going to the Security Council.

Second, they mentioned as the coequal purpose, the fulfillment of human rights and fundamental freedoms. That consecrated phrase was carried over, and on December 10,1948, all the nations of the earth at that time came together in Paris and said in essence, "We say and affirm the transcendence of human rights, without dissent;" South Africa alone abstained. At that moment you could say that human rights entered into customary international law.

Twenty years after that, in 1968, in Tehran, all of the people who make up customary international law, the nations and the savants and the jurists were there, saying yes, now the Universal Declaration of Human Rights is a part of global law. I saw that echoed once again last June in Vienna, at the World Conference on Human Rights sponsored by the United Nations. As a delegate of the American Bar Association, I participated for eight full days in this fantastic array of 154 governments and almost 2,000 non-governmental organizations, declaring to the world that human rights are universal, inprescribable and inalienable. And for the first time really since the Universal Declaration, all the nations came together, and it was a sight to behold. You had there representatives of the rights of refugees and women, and the people who are handicapped physically or emotionally or mentally, and the indigenous people and everywhere there were displays of what they want to do in the world.

Remember now that the 30 declarations of the Universal Declaration were subscribed to by all of those nations that I just mentioned. It was a sad event when the Cold War split the USSR and the U.S., so rather than going forward on the dream of having one document, one covenant with all of the human rights, they split them, as you know. But finally there was a reconciliation of sorts in 1966, and the political and the economic separate covenants were approved by the United Nations, and they were ratified by the sufficient number of states in 1976 . So, as the lawyers would say, they entered into force. Now, all of those things are operating without, I say with shame, the consent or the rati- 
fication of the United States.

If you want a wonderful encouraging book, read Philip Alston's recent book published by the Oxford University Press, on monitoring the human rights around the world. There was a description there by several expert authors of what these committees are doing to monitor the human rights convention. There are covenants now or committees at the U.N. and in Geneva that monitor the committee or the commission on racial discrimination, likewise one on women and children, and torture. Philip Alston heads the newest of them, namely monitoring economic rights.

There is not a single word about sovereignty in all of those documents. They just take it for granted that human rights are above and beyond the claims of any nation, and that there are certain rights which have now entered into force. These committees unfortunately do not have the power to penalize, but they have to power to shame people, and the compliance across the world is rather magnificent.

The most civilized nations come, for example, before the committee on the elimination of discrimination against women, and if they are found to be having some old practice that discriminates against women, they eliminate it. The new nations, such as the nations from Africa also will present their document to these 24 women who head the commission, and they will have pointed out to them all that is in violation of international law and they will go back to some far away land and they will correct it.

Reading the reports that continuously flow out of these commissions, you could say that something really is happening at the world level. You may say, "Well, why don't we hear about them in the Cleveland papers or elsewhere?" You will. Somebody is going to discover these commissions and say that they are hammering out a whole new world law. Let me talk about three things: first, about Canada and the United States, and what we can do in this area; secondly, about China and the great crisis that is there; and third and most important, about the projection on the economic rights. First, let me just remind the Canadians and all of us of the case of Sandra Lovelace, an Indian woman in Canada, who appealed to the Commission of the United Nations on Political Rights. To simplify the story, she eventually was told that they cannot dispossess her from the Indian Reservation, and the Canadian Parliament agreed to that, and some 40,000 native Canadians got their rights restored. Well, when you read something like this, you say that something is happening across the world.

I hope someday that you will visit Strasbourg and see the European Court and Commission on Human Rights in operation. The 40 volumes of decisions of this body that has been going since 1953 are really stunning. They take these casès and they adjudicate them against Ireland or France or England. Likewise, something like what is 
happening in Costa Rica. It is not as developed, this Inter-American court, but it would develop a great deal more if the United States ratified the treaty and if we had an American judge there.

Well, does all of this mean that we are moving into a New World? It seems so slow. But remember that the Magna Carta was hardly recognized for 200 or 300 years after that. Remember also that it was only a government that came in and said that it should be the law of the land, and that we are proclaiming the law of the world in this area.

Let me use El Salvador as an example. I was there just before the election as an observer with eight others on human rights and I discovered something that I had not known before. As you know El Salvador in the legislature gave amnesty to all the of the thugs who killed the Jesuits and so many others. When the U.N. truth commission came out it indicted all of those people, and the legislature said that in order to promote reconciliation, they will give amnesty to the all of these people. We discovered, however, that it is specifically stated in the constitution of El Salvador that "No amnesty may be given for crimes committed during the presidency of the President who signs the amnesty decree."

Christianity had no right to do this, and this summer I am working with a student from Georgetown whose mother is from El Salvador and we hope to ask and receive an advisory opinion from the InterAmerican Court in Costa Rica, to the effect that El Salvador had no right to go against their constitution in granting amnesty. That would be a warning to other nations that they cannot go against their own constitution when they give amnesty.

Let me come to my three points. First, what Canada and the United States could do together for human rights. There is a remarkable symbiosis between these two great countries; we are not really different at all. We have our own diversity and our distinction, but we share the same law and the same tradition, and we saw the moral power of the United States and Canada, when both of them became the first and only non-European nations to join the Helsinki Agreement. The North Americans added a great deal to that process, which is ultimately responsible for the emancipation of Eastern Europe. But what could the United States and Canada do concerning Latin America? We all feel badly that Latin America is suffering so terribly. There has been a movement towards democracy, but we have here 400 million other Americans, fellow Americans, who need help very desperately.

Canada is a member of the Inter-American Commission, which litigates to help people. The United States should be a member, and I hope that the Clinton Administration is going to move rapidly to finally ratify the treaty, albeit with some reservations.

The United States made a commitment in 1976 that we will do what we should be doing through the United Nations. Section 502(b) 
of the International Assistance Act was passed, which says that, "no nation shall receive aid from the United States if that nation is not in compliance with internationally recognized human rights." The State Department implements and executes the Act. President Carter was fantastic on that and I hope that President Clinton is going to improve his record in that area.

Canada and the United States could do all types of things together. We saw what we could do in NAFTA, and that is opening up all types of new areas. Incidentally, I wish you Canadians would export your wonderful system of gun control to the United States. Come and tell us how to do it. Five years ago I participated in a law conference at Harvard University on gun control or the lack of gun control in America, and we stood in admiration of what Canada does in this area, and we were ashamed that we kill, murder thousands of people every year.

These two great nations could use their collective economic power to elevate the standards of human rights, especially towards Africa, the poorest nation. We saw in Rwanda the chaos that may be coming. 51 nations, most of them subjugated by colonial powers, now are emerging and they need all types of joint ventures from the rich nations of $\mathrm{Ca}$ nada and the United States. Joint ventures in education, land development, improvements in government. Canada is very highly regarded on the continent of Africa, but the United States is less so because of our dismal record in bringing slaves from that continent to the United States and the way we treat our fellow Africans.

We could have all types of partnerships in environmental things for example. Why do we not do things like this? Well, we do, but it is just beginning. That is why this Canada/United States Law Institute is so important; I wish that we had these institutes all over the country. I wish in many ways that we were similarly, just doing things as if $\mathrm{Ca}$ nada and the United States were almost the same entity. We are the same entity. Why can we not collaborate more?

Now as we look at the entire world, it seems to me that we have to say that the power, the combined moral and political and economic power of North America is such that we ought to do more in this area. I am familiar with the non-governmental groups in Canada, Amnesty International, of course, and all of the others. They are collaborating in all types of new ways, and they are prominent, for example, in the establishment of the new International Criminal Court in former Yugoslavia. I was present in 1968 in Montreal, at a universal worldwide convention on human rights, and there, as at Tehran, the Canadians and all of us agreed that the Universal Declaration is a part of customary international law. I am less familiar with the Canadian Bar Association than I should be, but I welcome their collaboration with the American Bar Association, which frankly has been transformed. We 
now have Goal 8 to extend the rule of law across the world. The American Bar Association sends out Rule of Law letters to tyrants across the country, and we also send observers to trials of political prisoners in the world.

Let me come to my second point about China. I am, as all of us are, still stunned at the events at Tiananmen Square five years ago. We look at China and we say, well there has to be something done, and we feel very frustrated because the language is so complex, and we seemingly know so little about this country. There are thousands of people in re-education camps; the Voice of America is jammed; the Red Cross is not even allowed to visit; there is repression of the press, and of the churches and the right of assembly; and religion is crudely and cruelly crushed. For example, there are at least ten Jesuits I know of in jail. Additionally, we all know that abortion is virtually required of thousands, perhaps millions of people. And Tibet is still being denied fundamental rights after the take over by China many years ago.

Remember that China was present in 1945 at the formation of the United Nations. They accepted the Universal Declaration in "48. They accepted the economic and political rights, and they are a part of the world community. They have approximately one-fifth or one-fourth of humanity.

President Clinton has to make a decision before June 3, as to whether the Most Favored Nation Status will be continued. President Bush vetoed a measure to take that back on two occasions, saying that we need trade with these people, and a year ago Clinton in essence punted. The deliberations at the highest level are very, very important. I do not know how well they are going. We are all weighing the options as to what could happen. This is an opportunity for the entire world at this particular moment. It is an opportunity particularly for Canadians and Americans.

America has a deep, deep interest involved in this. Reebok imports all of those expensive shoes with great profit. Toys-R-Us makes bonanzas. A delegation from Reebok was in China lately. They are very apprehensive that maybe it will come out that some of these shoes are made by children and slaves and prisoners, and they do not want that to happen. And the President of Reebok is a very wonderful man, Mr. Fireman, devoted to human rights.

I urge that the Canadians and the Americans and all of us say to every industry involved in China, that you have to do what the industries in South Africa did, namely to develop some Sullivan Principles. The Sullivan Principles were for fair employment. It seems to me that it is a rational, wonderful thing for American and Canadian governments to say to these people, "You go and say to the Chinese, "we are not going to trade with you; we will not import your things, unless you live up to these basic international guarantees, that you yourself recog- 
nized 50 years ago." "We are not asking them to do something that is western. We are simply asking them to live up to the basic standard of human decency agreed to by all of mankind.

Unfortunately, the United Nations is not about to lead in this area; China after all has the veto power in the Security Council. But it seems to me that the U.S. and Canada and any other nation that will join, by very firm diplomacy, can keep reminding these people that they are not in compliance with the basic instincts of humanity.

Last month a group in Washington asked me if I would spend 2 hours with 12 Chinese jurists. I agreed and went and gave a spiel about human rights, because that is what they wanted. I showed them the document that had just come out from Asia Watch. It consisted of 980 pages documenting all the gross abuses. The 12 jurists kind of turned on me after my 20 minutes, and it was very clear that they were not going to listen to this. The most eminent of them who had been the Ambassador to Australia from Beijing, just said, "You Americans should tend to your own problems. You have got a lot of murders in this city and all of these other things." Okay, we have heard this before. He and the others said, these are western values and you have no right to infringe - are you ready for this - on our sovereignty. So I tried to quietly say, "You do not have any powers under sovereignty to violate basic things in international law to which you have agreed."

It was not a stormy session. It was very quiet, but it seemed to me clear then and even clearer now, that these people were in the government. They are Marxists and communists, and they know that if there is any real agitation among 1.2 billion people, that they could lose power very easily. And they all know that Deng Xioping is going to move on to his reward soon, or suddenly, and they are afraid of turmoil. They also know that if they allow the United States to push them around on this, that they may lose the trade, but right now their mood is: "We are so intent on keeping these people locked into this authoritarian model, that we will tolerate another Tiananmen Square."

It seems to me that we have to advance our interest and our ideals. I am afraid that come June 3, the interest of the United States will take precedence over the ideals. Clearly, we have interests; there is $\$ 40$ billion of trade coming in, and China needs us. The wheat people, for example, say please do not jeopardize this. They will retaliate if we snap the Most Favored Nation, and it will be bad for everybody.

Simultaneously with protecting these interests, which are genuine, we should say that we want to advance our ideals. Could we not have an international conference of all the trading partners of China? Can we not say that we will quietly set forth an ultimatum, and that we are not going to continue to deal with China and benefit China as long as China treats its people in the following ways which violate international law. Will it work? We are not certain. But you would have worldwide 
attention to these problems.

I think that the United States and Canada can take some credit for the change in South Africa. I remember when the American Bar Association finally came out in favor of economic sanctions against South Africa, and I was asked to testify along with two former presidents of the ABA before the Senate. The moment that the Senate learned that the ABA wanted economic sanctions, everything changed. They passed a bill, the House passed a bill, Ronald Reagan vetoed it, and to the amazement of everybody, $2 / 3$ overrode the veto of President Reagan, and economic sanctions were placed. One hundred American corporations were told to pull out of South Africa, and immediately South Africa said, "Well we have got to do something," and it evolved such that they are now going to have multi-racial elections for the first time next week.

We have all types of power between us. Can we not mobilize world opinion against China selling weapons to whom they should not be? They have a widespread use of the death penalty, and that is arguably against international law, and they have a long train of abuses. This is documented by Amnesty, by the State Department, by any number of people. Shall we just continue with business as usual?

It is China's duty under Article 55 and 56 of the Universal Declaration of Human Rights to correct this entire situation. Could the United States and China lose some trade? It is possible, but it seems to me that this is a moment of truth, when we have to say, "Well, we stand for something." We can look at this in long-range and say, "We better continue what we are doing now, because otherwise we could precipitate a period of severe instability." That is true. No one knows what is going to happen in China after the change of government. There is going to be a vast industrialization. It is beyond belief what is going to happen to that country, and clearly for our interests we want to be there.

Someone theorized the other day that with the mechanization of farms, which is now happening, you will have millions of Chinese coming into the cities. They will be unemployed. We should recognize furthermore that for a 1,000 years they have had an authoritarian government that has been ground down, that has been enforced by 50 years of communism. Could we inadvertently add to the chaos? Those are all of the questions that we have to consider then in a civilized way. Both of these nations need to bring in the world in a big dialogue.

Let me come to my third point. Now is the time to fulfill them. A couple of years ago I gave a series of lectures at Oxford, at the law school, and I gave one series as nine lectures on human rights. I kept the economic rights until the end of the lecture, and during the question period a man from the Third World said, "Why did you put these at the very end, as if they were not very important? That is the biggest 
thing."

I was very insensitive to the fact that the people in the Third World make up about two-thirds of humanity or more. They lack political rights, but economic rights of food and education and housing are really much more important for them. Let us look at the grim statistics. Before the year 2000, the population of the earth will grow from 5.2 billion to 6.2 billion, 1 billion human beings coming into the world in those 6 years. No planning, no program. People do not even know that they are going to come. Clearly, this is a monumental problem, not merely for those nations, but for all of us. In Bangladesh they now have a population of 150 million in a place the size of Florida. The United States only has $4 \%$ of the population of the earth; we consume at least $40 \%$ of groceries. Let us look at children. If you want to weep, 40,000 children die needlessly everyday, and during this important conference, 100,000 children in the world will die of preventable disease.

One of my icons, along with Henry's, an American lawyer, called together the World Summit on Children in 1990. Every nation contributes $\mathrm{X}$ amount, and with that money they are literally able to save the lives of millions of children. In Bosnia we have really no idea of the agony that is gone through everyday.

Two years ago I attended a conference on human rights. One afternoon an American brought me out to look at the cemetery, with thousands of tiny little white crosses, and this priest said that he buries 15 or 20 children a week. They die of preventable causes. Now think of the anguish of the parents and the anger that they have against organized society.

I commend to you a beautiful book by Philip Alston, once again on the right to food. And if there is anything that is clear in international law, it is that a people do have the basic right to food, to sustenance. It is possible. Everyone says that 3000 calories for every individual are available; the resources are there. Again, the United States and Canada, with a collaboration between us, and between the whole world, could in a generation or two, resolve this problem. How could you do that? Just use the non-governmental groups. I saw their moral and physical power once again in Vienna. There were groups like Bread for the World, an American NGO that does precisely what its title suggests.

Give these people incentives, give them tax writeoffs, give them all of the creative things that lawyers can do.

We all know about the UNDP, the development fund. It has maybe $\$ 700$ million a year. It sounds big but it really is not. The right to development is the thing that the Third World speaks about all of the time. This is clearly consistent with what my church has been doing since Vatican II, namely preaching the linking of peace in justice and faith in justice. And it seems to me that the notion of sovereignty 
should not impede us.

Let us give up some ultimate conclusion. We are not preaching something that is new in the history of humanity. I came across this the other day in the Code of Hammurabi. Two thousand years before Christ, Hammurabi says that the law is designed "to make justice reign, to destroy the wicked and the violent, to prevent the strong from opposing the weak." That is what we are doing now at a world level, to prevent the strong from opposing the weak. Roman law certainly does that, and Magna Carta proclaims that to the whole world.

Human rights it seems to me are there, and they are something that is emerging in our soles. When people say "Where are all of those rights coming from?" I just say from the conscience of humanity.

I must say I was thrilled when President Bush signed the Americans with Disabilities Act. We had worked on that a long time in the Congress, about 10 or 15 years. Finally it is the law, and we recognize that society has an obligation not to discriminate in any way against those individuals who have personal or physical or emotional or mental difficulties.

President Kennedy said it well: "Those who make peaceful revolution impossible make violent revolution inevitable." We in the Bar and in business are very important people, and if we make peaceful revolution impossible, we invite violent revolution. Those 5,400 words of the U.S. Constitution have wonderful terms like "due process," "equal protection," "freedom of religion and speech," and they echo the Magna Carta, and they echo what is in our soles.

I came across the following the other day from Governor Winthrop, the first governor of Massachusetts. It sounds old, but it seems to me that we need leaders who will proclaim this message: Governor Winthrop said, "We must love one another with a pure heart fervently. We must delight in each other, make each other's condition our own, rejoice together, mourn together and suffer together. We must be knit together as one." Saint Paul said the same thing centuries ago, when he said that love is patient and kind, and love is the one thing that still stands when all else has fallen. As lawyers and economists, we do not use the language of love, but it seems to me that law is another way of saying that we love all of these human beings, because they are very precious. They have these rights, and those rights are universal and cannot be trampled upon.

Let me just close before your comments and questions by saying that the potential for progress at this moment in history is greater than ever before. We made great progress as a country after World War II, and when we look back, we are grateful to the leaders that brought about Nuremberg, that established many of these principles; the formation of the United Nations; the Marshall Plan and so many other things. And now we have even more opportunities with the collapse of 
the cold war.

Let us dream that Canada and the United States and all the other nations could collaborate together. If we pushed on arms control, could we possibly transfer the $\$ 900$ billion which humanity each year spends on arms, into food and books and medicine for children? We are both moral nations. George Santiana put it well, "Being an American is in and of itself almost a moral condition."

Let me close with a quotation from a fellow lawyer, Archibald Mac Leish, that sums up everything I have been trying to say. Archibald Mac Leish graduated from Harvard Law School, practiced law in Boston, then went off the do important things like writing poetry, and he ended up as the Librarian of Congress. Here is what he said: "There are those who will say that the liberation of humanity, the freedom of man and mind are nothing but a dream. They are right. It is a dream; it is the American dream."

Thank you very much, do you have some comments, questions or better jokes? 
